\title{
Characterisation of $\mathrm{La}_{0.6} \mathrm{Sr}_{0.4} \mathrm{Co}_{0.2} \mathrm{Fe}_{0.8} \mathrm{O}_{3-\delta^{-}} \mathrm{Ba}_{0.5} \mathrm{Sr}_{0.5} \mathrm{Co}_{0.8} \mathrm{Fe}_{0.2} \mathrm{O}_{3-8}$ composite as cathode for solid oxide fuel cells
}

\author{
Maria Paola Carpanese ${ }^{1,2}$, Davide Clematis ${ }^{1 *}$, Massimo Viviani ${ }^{2}$, Sabrina Presto ${ }^{2}$, Marco Panizza ${ }^{1}$, Giacomo \\ Cerisola $^{1}$, Antonio Barbucci ${ }^{1,2}$ \\ ${ }^{1}$ Department of Civil, Chemical and Environmental Engineering (DICCA), University of Genoa, P. le J. F. Kennedy 1, \\ I-16129 Genova, Italy \\ ${ }^{2}$ Institute of Condensed Matter Chemistry and Technology for Energy, National Research Council (CNR-ICMATE), Via \\ De Marini 6, 16149 Genova, Italy
}

Received August 14, 2017; Accepted September 24, 2017

Mixture of $\mathrm{La}_{0.6} \mathrm{Sr}_{0.4} \mathrm{Co}_{0.2} \mathrm{Fe}_{0.8} \mathrm{O}_{3-\delta}$ and $\mathrm{Ba}_{0.5} \mathrm{Sr}_{0.5} \mathrm{Co}_{0.8} \mathrm{Fe}_{0.2} \mathrm{O}_{3-\delta}$, was investigated as promising cathode for intermediate temperature solid oxide fuel cells (IT-SOFCs). The two perovskites possess high catalytic activity for the oxygen reduction (ORR), although some problems related to their chemical and structural stability have still to be overcome in view of improving durability of the cell performance. The achievement of a stable and high-performing composite material is the aim of this study. In principle, chemical equilibrium at the LSCF-BSCF interface may be reached through ions interdiffusion during the sintering process, resulting in the chemical stabilization of the material. The composite-cathode deposited on $\mathrm{Ce}_{0.8} \mathrm{Sm}_{0.2} \mathrm{O}_{2-\delta}$ electrolyte was then investigated by Electrochemical Impedance Spectroscopy (EIS) as a function of temperature, overpotential and time. The results exhibited an interesting electrochemical behavior of the electrode toward oxygen reduction reaction. XRD analysis was performed to detect structural modification during thermal or operation stages and it was found that after the sintering the two starting perovskites were no longer present; a new phase with a rhombohedral $\mathrm{La}_{0,4} \mathrm{Sr}_{0,6} \mathrm{FeO}_{3}$-type structure (LSF) is formed. An improvement in composite cathode durability has been detected under the considered operating conditions $\left(200 \mathrm{mAcm}^{-}\right.$ ${ }^{2}, 700{ }^{\circ} \mathrm{C}$ ) in comparison with the pure BSCF electrode. The results confirmed this new electrode as promising system for further investigation as IT-SOFC cathode.

Keywords: SOFC cathode, long-term stability, LSCF-BSCF.

\section{INTRODUCTION}

One of the main goals for solid oxide fuel cells is the reduction of operating temperature below $800{ }^{\circ} \mathrm{C}$ to improve long-term stability and reduce costs. On the other hand the lowering of operating temperature causes a reduction in performance, mainly due to the high activation energy required for oxygen reduction reaction at the cathode [1,2].

Different efforts have been made to investigate new kind of materials and microstructure with the aim to understand which phenomena are responsible of the cathode performance changes as a function of time, thermal cycling, operating conditions and others factors [1,3-5].

One class of materials widely investigated are perovskite, with a general formula $\mathrm{ABO}_{3}$; the A-site is occupied by lanthanides or alkaline earth metals, $\mathrm{B}$-site contains cations of transition metal as $\mathrm{Fe}$ and Co. In particular the attention has been focused on the materials that shown a large ionic and electronic conductivity with a good electrocatalytic reduction of oxygen [6].
$\mathrm{Ba}_{0.5} \mathrm{Sr}_{0.5} \mathrm{Co}_{0.8} \mathrm{Fe}_{0.2} \mathrm{O}_{3-\delta} \quad$ (BSCF) and $\mathrm{La}_{0.6} \mathrm{Sr}_{0.4} \mathrm{Co}_{0.2} \mathrm{Fe}_{0.8} \mathrm{O}_{3-\delta}$ (LSCF) are two perovskites evaluated as promising cathode materials by several studies [7,8]. Excellent properties of BSCF were presented by Shao et al. [9] at the beginning of 2000. This material showed a very high performance for temperature lower than $600{ }^{\circ} \mathrm{C}$.

LSCF has been considered a possible electrode material thank to its electronic conductivity, over $300 \mathrm{~S} \cdot \mathrm{cm}^{-1}$ and oxygen conductivity near to $0.1 \mathrm{~S} \cdot \mathrm{cm}^{-1}$ at $800{ }^{\circ} \mathrm{C}$, with consequent good results $[10,11]$.

Nevertheless these two materials are affected by two main problems: stability and durability. LSCF suffers of La and Srinter diffusion pointed as the reason of degradation; in fact the cation interdiffusion to electrode/electrolyte interface leads to the formation of an insulating phases as $\mathrm{La}_{2} \mathrm{Zr}_{2} \mathrm{O}_{7}$ (LZO) or $\mathrm{SrZrO}_{3}$ (SZO) when yttrium stabilised zirconia (YSZ) is used as electrolyte $[12,13]$. The presence of these phases has a negative effect on ionic conductivity, reducing the global cell performance. A possible solution, to avoid the

\footnotetext{
* To whom all correspondence should be sent. E-mail: davide.clematis@edu.unige.it
}

(C) 2018 Bulgarian Academy of Sciences, Union of Chemists in Bulgaria 


\section{P. Carpanese et al.: Characterisation of $\mathrm{La}_{0.6} \mathrm{Sr}_{0.4} \mathrm{Co}_{0.2} \mathrm{Fe}_{0.8} \mathrm{O}_{3-\delta}-\mathrm{Ba}_{0.5} \mathrm{Sr}_{0.5} \mathrm{Co}_{0.8} \mathrm{Fe}_{0.2} \mathrm{O}_{3-\delta \ldots}$}

formation of the insulating layer, is the application of an interlayer made by $\mathrm{Gd}_{0.2} \mathrm{Ce}_{0.8} \mathrm{O}_{3-\delta}$ (GDC) or $\mathrm{Sm}_{0.2} \mathrm{Ce}_{0.8} \mathrm{O}_{3-\delta} \quad$ (SDC) between cathode and electrolyte or as directly as electrode [13,14].

A further solution to block the $\mathrm{Sr}$ segregation is the modification of surface chemistry through the infiltration technique. In this case LSCF cathode backbone was infiltrated by a stable compound rich in $\operatorname{Sr}[15]$, with the formation of a phase spread over all the surface. Other possible technique proposed by different authors are the preparation of composite materials [16-18] or the introduction of A-site deficiency.

About BSCF structural instability represents the main issue; the material for temperature below $900{ }^{\circ} \mathrm{C}$ suffers a phase transition and the cubic active phase evolves into an hexagonal structure that has a lower catalytic activity. The literature attributes this instability to a lattice distortion $[22,23]$ caused by the changing valence of B-site cations, and also by doping quantity of A-site cations [25]. A second, but relevant problem, which affects BSCF is the formation of carbonates if exposed to $\mathrm{CO}_{2}$ containing atmosphere, even for low concentration $[28,29]$.

Known the problems introduced above, the aim of this study is exploit the excellent properties of these two materials, through a composite cathode made mixing the two powders. The base of the investigation is the assumption that the mixing could result in their mutual structural stabilisation, preserving a sufficient electrocatalytic activity. The composite electrode was investigated under structural, microstructural and electrochemical point of view. Influence of operating temperature and applied overpotential were investigated through equivalent circuit analysis and also a long-term stability behaviour was observed. Obtained results were compared with those obtained from LSCF and BSCF pure electrode.

\section{EXPERIMENTAL}

A set of samples of technically pure The LSCFBSCF composite powder was prepared by mixing 50 vol. \% LSCF (Fuel Cell Materials) and 50 vol. \% BSCF (Treibacher) powders in ethanol, through a low energy ball milling for 20 hours at R.T.

The obtained paste was freeze-dried for 24 hours at $-40{ }^{\circ} \mathrm{C}$ and $0.22 \mathrm{mbar}$ (Labconco Free Zone 2.5), then, sieved for 30 minutes to separate powder from balls.

Electrolyte substrates were fabricated from $\mathrm{Ce}_{0.8} \mathrm{Sm}_{0.2} \mathrm{O}_{2-\delta}$ powders (SDC20-HP, Fuel Cell Materials) by cold pressing at $60 \mathrm{MPa}$, followed by one-step sintering at $1450^{\circ} \mathrm{C}$ for 5 hours in air. The resulting electrolyte disks had a diameter of $25 \mathrm{~mm}$ and a thickness of $1.2 \mathrm{~mm}$.

The LSCF-BSCF composite powders were mixed in a mortar with alpha-therpineol (techn. $90 \%$, Sigma Aldrich) to obtain a mixture suitable for deposition. The ink was deposited by slurry coating, using a shaped-mask and a blade to obtain symmetrical layers on both sides of the SDC pellets, thus obtaining working electrode, WE, and counter electrode, CE. On one side of the cell a ring reference electrode, RE, used for three-electrode measurements and made by the same cathode slurry, was deposited around the WE. Its distance was equal to 3 times the electrolyte thickness, in order to avoid possible reference electrode polarization [30,31]. Sintering followed at $1100{ }^{\circ} \mathrm{C}$ for 2 hours. The thickness of the porous sintered electrodes was 30 $\mu \mathrm{m}$ while the geometric electrode area was about $0.28 \mathrm{~cm}^{2}$. Composition mismatches and asymmetry of the electrodes were carefully considered to avoid appearance of artifacts in the impedance spectra [32].

Electrochemical impedance spectroscopy was used to investigate the electrocatalytic activity of the composite cathode in the three-electrode configuration. The sample was placed in a labconstructed test station [33]. Pt meshes were placed as current collectors on the surface of the WE and $\mathrm{CE}$ and connected by $\mathrm{Pt}$ wires to a potentiostat coupled to a frequency response analyser (Autolab PSSTAT302N).

Impedance measurements were performed in the temperature range of $500-800^{\circ} \mathrm{C}$, at open circuit voltage (OCV) and at applied cathodic overpotentials (up to $-0.2 \mathrm{~V}$ ), by applying a perturbation of $10 \mathrm{mV}$ in a $0.1 \mathrm{~Hz}-100 \mathrm{kHz}$ frequency range.

To analyse the cathode degradation a direct current (dc) load of $200 \mathrm{~mA} \cdot \mathrm{cm}^{-2}$ was applied for 200 $\mathrm{h}$, while the impedance measurements were collected at OCV after interruption of the load at different times.

To understand the kinetic of the reaction process, all the impedance data were analysed by ZView $^{\mathcal{O}}$ software (Scribner Associates Inc.), using an equivalent circuit (EC) to model the cathode behaviour. The selected EC was formed from an electrolyte resistance $\left(R_{s}\right)$ connected in series with two sub-circuits, each composed by a resistance (R) in parallel with a constant phase element (CPE).

In order to identify the crystalline phases and any second phase, the composite powder, the as sintered electrode and the tested electrode were analysed by X-ray diffraction (XRD), using a PAN analytical X'pert diffractometer with $\mathrm{Cu}-\mathrm{K}_{\alpha}$ incident 


\section{P. Carpanese et al.: Characterisation of $\mathrm{La}_{0.6 \mathrm{~S}} \mathrm{Sr}_{0.4} \mathrm{Co}_{0.2} \mathrm{Fe}_{0.8} \mathrm{O}_{3-\delta}-\mathrm{Ba}_{0.5} \mathrm{Sr}_{0.5} \mathrm{Co}_{0.8} \mathrm{Fe} e_{0.2} \mathrm{O}_{3-\delta \ldots}$}

radiation. The spectra were collected over the angular range $20^{\circ}<2 \square<90^{\circ}$, in a constant scan mode with steps of $0.02^{\circ}$ and a counting time of $40 \mathrm{~s}$.

The microstructural investigation was performed through a Scanning Electron Microscopy (Hitachi SU3500) equipped with EDX detector. The porosity of the electrode was determined by an image analysis (Image $\mathbf{J}$ software).

\section{RESULTS AND DISCUSSIONS}

Fig. 1 reports the cross-section of the cathode/electrolyte interface, after the sintering of the mixed powders at $1100^{\circ}$ for $2 \mathrm{~h}$. The electrode structure is well-interconnected, though the porosity appears a little irregular. From the same image a good adhesion at the electrode/ electrolyte interface was detected.

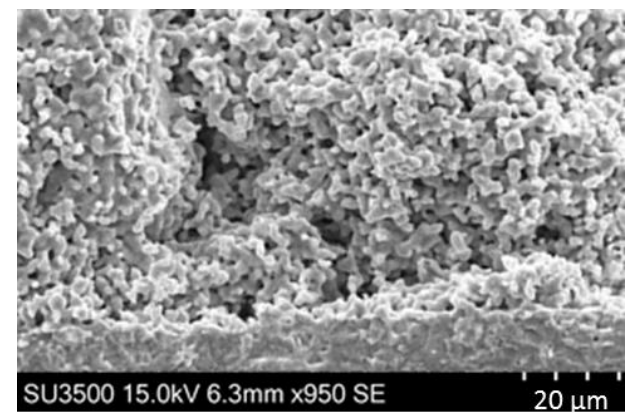

Fig. 1. Image of cross section of the cathode/electrolyte interface after the sintering treatment at $1100{ }^{\circ} \mathrm{C} \mathrm{x} 2 \mathrm{~h}$.

The XRD analysis of the LSCF - BSCF composite electrode, as sintered cathode and after electrochemical testing do not show any evident formation of new phases (Fig. 2a). The electrode structure is stable, however the original powders structure has remarkably changed during the sintering thermal treatment. In fact excluding the highest peaks attributed to the SDC substrate LSCF and BSCF phase (Fig 2b) were no longer detected after the sintering step. While, it is possible to identify a new phase with a rhombohedral $\mathrm{La}_{0,4} \mathrm{Sr}_{0,6} \mathrm{FeO}_{3}$-type structure (LSF).

However, from these results it is not possible to exclude the presence of a $\mathrm{La}_{0.5} \mathrm{Ba}_{0.5} \mathrm{CoO}_{3}$ Co-rich cubic phase (LBC), because all its peaks are completely overlapped with those of LSF.

It is evident that during the sintering stage a strong interdiffusion between the starting ceramic powders occurred, leading to a heavy structural modification involved not only the interface between the two materials but the entire composite volume. Further investigation to better clarify the nature of the new electrode structure is object of future studies.

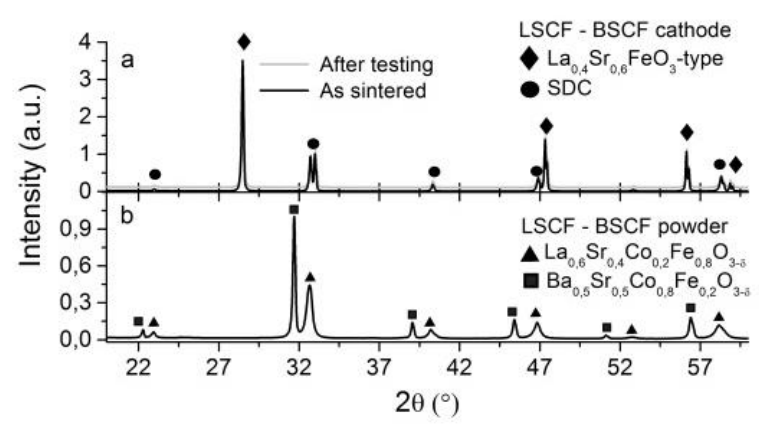

Fig. 2. (a) XRD spectra of the LSCF-BSCF composite cathode after sintering at $1100{ }^{\circ} \mathrm{C} \times 2 \mathrm{~h}$ (as-sintered, black pattern) and after testing (grey pattern). (b) XRD spectra of the LSCF - BSCF powder after mechanical mixing.

The polarization resistance $\left(\mathrm{R}_{\mathrm{P}}\right)$ of the composite cathode was obtained from electrochemical impedance spectroscopy analysis (EIS) on the composite half-cell in three electrode configuration. Fig. 3 summarizes the values obtained at different temperature. In this graph the composite cathode resistance was compared with those obtained for LSCF and BSCF pure electrode deposited on SDC substrate. Polarization resistance of the composite stays between those of BSCF and LSCF in the whole temperature range. Considering the Arrhenius behaviour the apparent activation energies $\left(E_{\text {act }}\right)$ was calculated. The composite had the lowest valued $1 \mathrm{eV}\left(96 \mathrm{~kJ} \mathrm{~mol}^{-1}\right)$, while BSCF and LSCF had $E_{\text {act }}$ of $1.18 \mathrm{eV}\left(113 \mathrm{~kJ} \mathrm{~mol}^{-1}\right)$ and $1.52 \mathrm{eV}$ $\left(147 \mathrm{~kJ} \mathrm{~mol}^{-1}\right)$, respectively. The values extrapolated for the pure cathode were in accordance with literature (BSCF $\sim 116 \mathrm{~kJ} \mathrm{~mol}^{-1}[9,40], \mathrm{LSCF} \sim 140$ $\left.\mathrm{kJ} \mathrm{mol}^{-1}[41]\right)$.

The low $\mathrm{E}_{\text {act }}$ for the composite pointed out that this electrode is more active than BSCF at low temperature, while its higher value for $\mathrm{R}_{\mathrm{P}}$ could be attributed to small geometrical differences between the two porous structures.

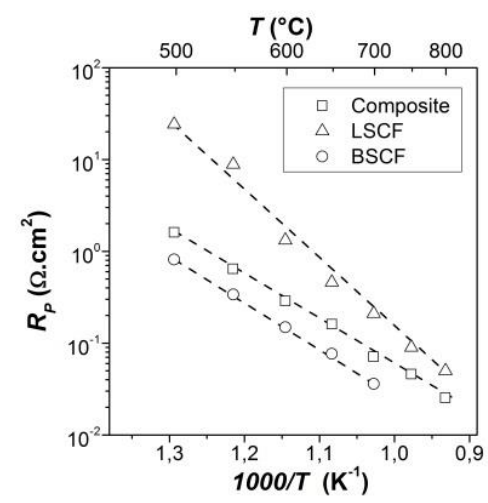

Fig. 3. Polarisation resistance $\left(\mathrm{R}_{\mathrm{p}}\right)$ versus temperature for the composite and commercial LSCF and BSCF cathodes. Calculated activation energies values: BSCF, $1.18 \mathrm{eV}$ $\left(113 \mathrm{~kJ} \mathrm{~mol}^{-1}\right)$; composite, $1 \mathrm{eV}\left(96 \mathrm{~kJ} \mathrm{~mol}^{-1}\right)$; LSCF, 1.52 $\mathrm{eV}\left(147 \mathrm{~kJ} \mathrm{~mol}^{-1}\right)$. 


\section{P. Carpanese et al.: Characterisation of $\mathrm{La}_{0.6} \mathrm{Sr}_{0.4} \mathrm{Co}_{0.2} \mathrm{Fe}_{0.8} \mathrm{O}_{3-\delta}-\mathrm{Ba}_{0.5} \mathrm{Sr}_{0.5} \mathrm{Co}_{0.8} \mathrm{Fe}_{0.2} \mathrm{O}_{3-\delta \ldots}$}

The impedance spectra were analysed. considering Jamnik interpretation [42], in agreement with different studies on mixed ionic electronic conductors $[38,39,43,44]$. In this analysis a wellknown equivalent circuit was chosen as reported in the inset of Fig. 4.

The equivalent circuit was made by a resistance $\left(\mathrm{R}_{\mathrm{s}}\right)$, ascribed to electrolyte resistance, in series with two identical sub-circuits. The first $\mathrm{R}_{\mathrm{HF}} / \mathrm{CPE}_{\mathrm{HF}}$ describes the high frequency part, and was associated to the charge transfer at the interface between cathode and electrolyte; the second subcircuit, $\mathrm{R}_{\mathrm{LF}} / / \mathrm{CPE}_{\mathrm{LF}}$ (low frequency), was linked to the electrode mechanism. In particular was assumed that $\mathrm{R}_{\mathrm{HF}}$ described the surface oxygen exchange resistance, and $\mathrm{CPE}_{\mathrm{HF}}$ was related to the charge stored in the cathode volume due to its high values $\left(1 \div 3 \mathrm{~F} \mathrm{~cm}^{2}\right)[45,46]$, and therefore was considered as a chemical capacitance. Fig. 4 shows experimental and fit curves, and confirms that this circuit is able to provide a good quality fitting at different temperature.

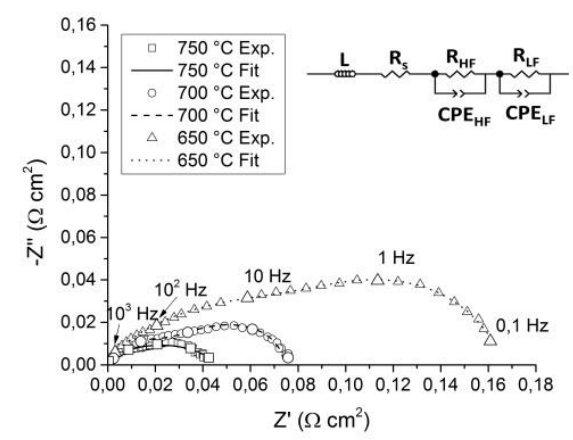

Fig. 4. Composite cathode impedance spectra obtained in the three-electrode configuration at $750{ }^{\circ} \mathrm{C}(\square), 700{ }^{\circ} \mathrm{C}$ (O) and $650{ }^{\circ} \mathrm{C}(\Delta)$ at OCV condition $\left.\mathrm{mol}^{-1}\right)$; LSCF, 1.52 $\mathrm{eV}\left(147 \mathrm{~kJ} \mathrm{~mol}^{-1}\right)$.

To obtain equivalent capacitance $\mathrm{C}_{\mathrm{LF}}$ and $\mathrm{C}_{\mathrm{HF}}$ from constant phase (CPE) parameters the following equation was used:

$$
C_{e q}=R^{\frac{1-n}{n}} \cdot Q^{\frac{1}{n}}
$$

where $R$ is the resistance of the R//CPE element $\left(\mathrm{R}_{\mathrm{LF}}\right.$ or $\mathrm{R}_{\mathrm{HF}}$ ), $Q$ is the module of the capacitance value and $n$ is the exponential parameter [47].

Table 1 summarizes resistance and capacitance values as a function of temperature for the two sub- circuits. $\mathrm{R}_{\mathrm{LF}}$ and $\mathrm{R}_{\mathrm{HF}}$ trend indicates that both the processes are thermally activated. The reduction of $\mathrm{C}_{\mathrm{HF}}$ as a function of temperature described a lower charge accumulation at the interface. Low frequency sub-circuit was connected with gas-electrode interaction $\left(\mathrm{R}_{\mathrm{LF}}\right)$ and electrode activity $\left(\mathrm{C}_{\mathrm{LF}}\right)$. The very low $R_{L F}$ values calculated confirmed a high performance for the oxygen surface exchange for composite cathode, while the chemical capacitance directly related with the oxygen vacancy concentration reached a maximum between 600 and $650{ }^{\circ} \mathrm{C}$ and then decreased.

Table 1: EIS fitting parameters for composite cathode as a function of temperature

\begin{tabular}{lllll}
\hline $\begin{array}{l}\text { Temper } \\
\text { ature }\end{array}$ & $\mathbf{R}_{\mathbf{H F}}$ & $\mathbf{R}_{\mathbf{L F}}$ & $\mathbf{C}_{\mathbf{H F}}$ & $\mathbf{C}_{\mathbf{L F}}$ \\
\hline $500^{\circ} \mathrm{C}$ & 0.374 & 1.825 & 0.395 & 0.913 \\
$550{ }^{\circ} \mathrm{C}$ & 0.092 & 0.774 & 0.341 & 0.955 \\
$600^{\circ} \mathrm{C}$ & 0.053 & 0.268 & 0.167 & 2.763 \\
$650{ }^{\circ} \mathrm{C}$ & 0.052 & 0.115 & 0.093 & 3.193 \\
$700^{\circ} \mathrm{C}$ & 0.027 & 0.052 & 0.067 & 1.49 \\
$750{ }^{\circ} \mathrm{C}$ & 0.011 & 0.031 & 0.075 & 0.932 \\
\hline
\end{tabular}

The composite cathode was investigated by EIS also in real cathodic conditions, applying a dc overpotential $(\eta)$. Total polarization resistance $\left(R_{p}\right)$ for composite cathode increases up to an application of $-80 \mathrm{mV}$ and remain constant at higher $\eta$. BSCF and LSCF showed an opposite behaviour; the first increases its $R_{P}$ while the second reduces $R_{P}$ when an overpotential was applied.

Fig. 5 reports $\mathrm{R}_{\mathrm{LF}}$ (Fig. 5a) and $\mathrm{C}_{\mathrm{LF}}$ (Fig. 5b) trends as a function of $\eta$ for all three tested cathodes. In literature is well reported that the application of $\eta$ to LSCF cathode promotes the formation of new vacancies, enhancing the activity for ORR with a decreasing of $\mathrm{R}_{\mathrm{LF}}[44,48,51,52]$. The behaviour describes above is recognisable in the two figures 5 (a and b). Composite $\mathrm{R}_{\mathrm{LF}}$ slightly decreases, indicating that the net flux of currents, generated by the applied cathode overpotential, helps surface activity. This higher surface activity can be due to the formation of new vacancies, as reported by Fig. $5 b$. 

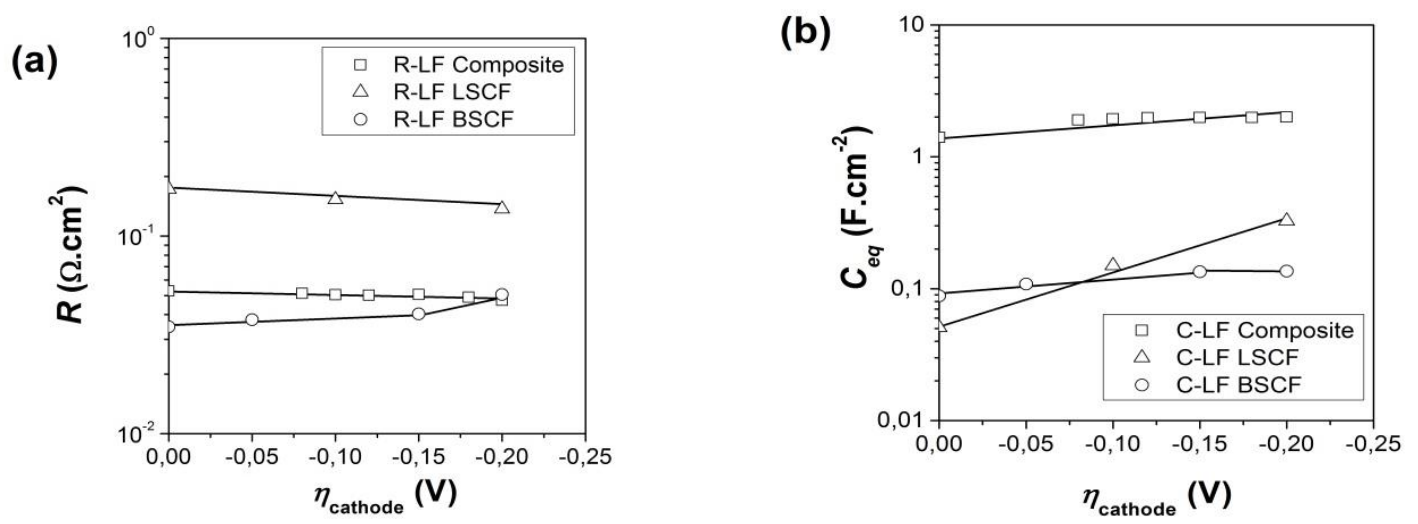

Fig. 5. (a) $R_{\mathrm{LF}}$ and (b) $\mathrm{C}_{\mathrm{LF}}$, for composite $(\square)$, commercial LSCF ( $\Delta$ ) and commercial BSCF ( $\bigcirc$ ) cathodes

Furthermore, as regards $\mathrm{C}_{\mathrm{LF}}$ trend with $\eta$ for the composite it shown an intermediate behaviour compared to the two starting materials. In fact, LSCF strongly increases its $\mathrm{C}_{\mathrm{LF}}$, while on BSCF a so strong effect was not detected. However the extremely high $\mathrm{C}_{\mathrm{LF}}$ value for composite, which means a higher ability to accommodate more oxygen vacancies, does not correspond to the lowest resistance and this behaviour remain an open issue.

One key point for cathode materials is their long-term stability. A first ageing investigation on the composite cathode was performed and results compared with BSCF pure electrode, which is considered as reference electrode as regards performance but presents many problem of stability, as reported in the introduction.

Ageing test was performed applying a current density of $200 \mathrm{~mA} \cdot \mathrm{cm}^{-2}$ at $700{ }^{\circ} \mathrm{C}$, and every 12 hours impedance measurements at $\mathrm{OCV}$ was done to evaluate $R_{P}$. Fig. 6 presents the $R_{P}$ trend for composite and BSCF cathode during an ageing test of 200 hours. The exposure time is in accordance with several literature works, that identified a period between $100-300 \mathrm{~h}$ as acceptable for a preliminary ageing test [53-56]. After $200 \mathrm{~h}$ composite cathode increased polarization resistance of about $5 \%$, which represents an important improvement if compared with the $38 \%$ of degradation shown by BSCF under the same operation condition. Moreover another positive factor is the absence of carbonates after testing that indicates a good stability of composite material in $\mathrm{CO}_{2}$-containing atmosphere.

A possible explanation of the composite performance loss could be due to some electrode morphological changes, as identified from SEM analysis (Fig. 7). In fact, if the XRD analysis does not detected any structural modification after testing, from image analysis (Fig. 7a and 7b) a reduction of porosity (from $42 \%$ to $35 \%$ ) was observed. The change of this parameter can affect polarization resistance, especially in the EIS low frequency arc, which describes oxygen surface exchange.

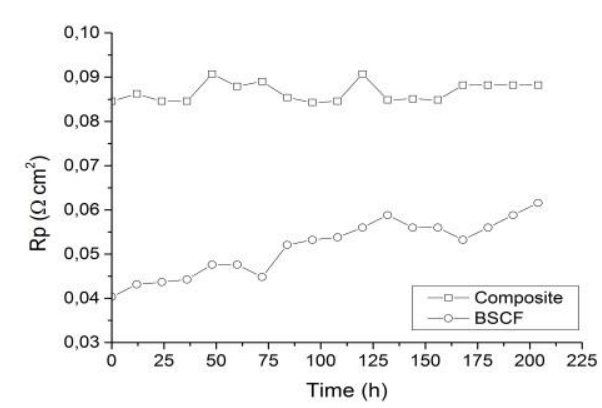

Fig. 6. Evolution of $R_{p}$ as a function of time for LSCF-BSCF cathode ( $\square$ ) and BSCF commercial cathode (O) during ageing with a current of $200 \mathrm{~mA} \mathrm{~cm}$ at 700 ${ }^{\circ} \mathrm{C}$.

SEM images analysis highlighted also the formation on new nano-particles $(\sim 50 \mathrm{~nm})$ on the cathode surface. However, EDX analysis is not able to confirm chemical composition of these particles because of the substrate interference during the measurement. The presence of nanoparticles on the surface was observed also for BSCF electrodes $[26,27,57]$; in this case the interference with cathode performance seems to be limited and the presence of this segregate phase not affect the electrocatalytic activity.

\section{CONCLUSIONS}

To our knowledge LSCF-BSCF composite electrodes are not yet studied in literature. The aim of this study was to obtain a mutual stabilisation between the two high-performing but unstable starting perovskites, without significantly losses on electrode performance. The electrode preparation is very easy by combining two commercial powders through a simple milling process. 
M. P. Carpanese et al.: Characterisation of $\mathrm{La}_{0.6} \mathrm{Sr}_{0.4} \mathrm{Co}_{0.2} \mathrm{Fe}_{0.8} \mathrm{O}_{3-\delta}-\mathrm{Ba}_{0.5} \mathrm{Sr}_{0.5} \mathrm{Co}_{0.8} \mathrm{Fe}_{0.2} \mathrm{O}_{3-\delta} \ldots$
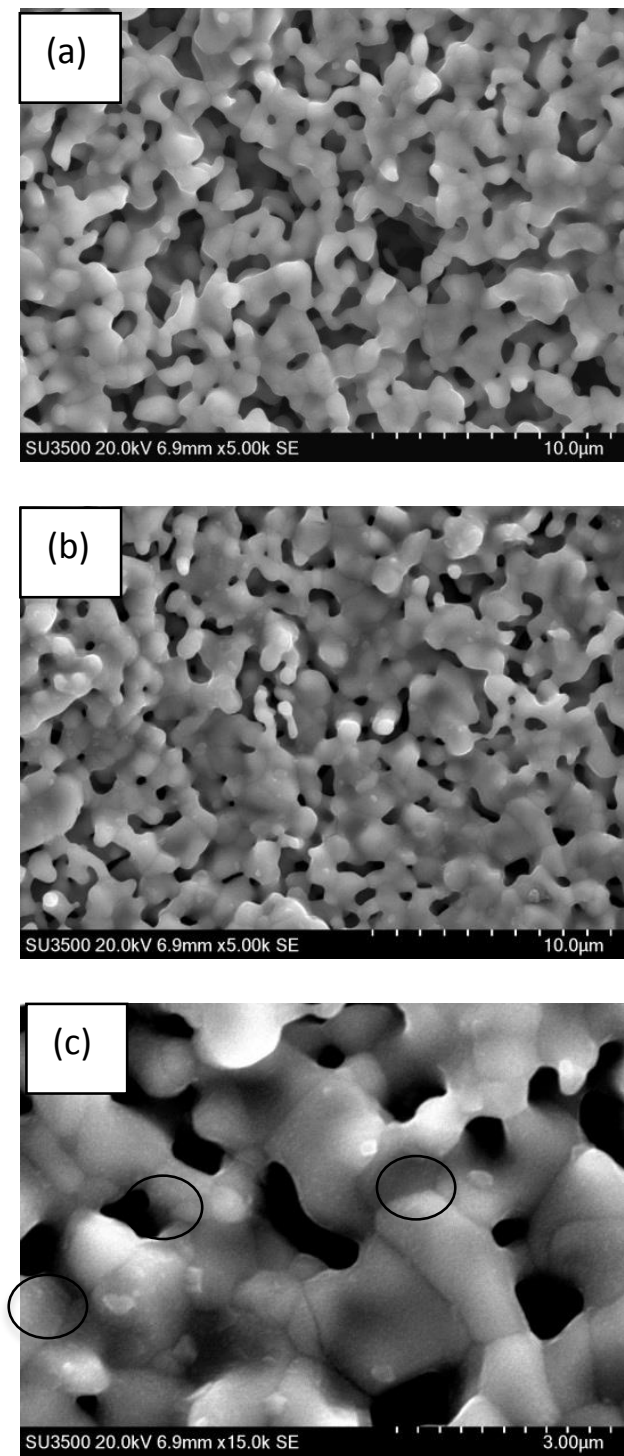

Fig. 7. SEM images of composite cathode surface before (a) and after (b, c) electrochemical test. In Figure (c) the circle identifies the formation of nanoparticles on the electrode surface.

The structural analysis performed on the powder and on the electrode, as sintered and after testing, showed that the two starting phases were no longer present after the sintering stage at $1100^{\circ} \mathrm{C}$. In other words, the starting composite was affected by a total structural transformation, which involved not only the interface but the whole cathode volume, resulting in a different electrode structure. The obtained new electrode globally demonstrated a high activity toward the ORR. In the range $500-800{ }^{\circ} \mathrm{C}$ an activation energy of $1 \mathrm{eV}\left(96 \mathrm{~kJ} \mathrm{~mol}^{-1}\right)$ was calculated, quite low if compared to the values obtained for other MIEC materials. Moreover, the results of the ageing test performed under current load of $200 \mathrm{~mA} \mathrm{~cm}^{-2}$ gave evidence of an impedance degradation much lower that the degradation measured for BSCF under the same ageing conditions.
In conclusion, it is demonstrated that the composite LSCF-BSCF cathode is an interesting system, worth to be investigated for its possible application in IT-SOFCs.

\section{REFERENCES}

1. S.B. Adler, Chem. Rev.104, 4791 (2004).

2. J.A. Kilner, M. Burriel, Annu. Rev. Mater. Res. 44, 365 (2014).

3. M.R. Cesário, D.A. MacEdo, A.E. Martinelli, R.M. Nascimento, B.S. Barros, D.M.A. Melo, Cryst. Res. Technol., 47, 723 (2012).

4. M. Liu, M.E. Lynch, K. Blinn, F.M. Alamgir, Y. Choi, Mater. Today.14, 534 (2011).

5. Q. Liu, X. Dong, G. Xiao, F. Zhao, F. Chen, Adv. Mater., 22 , 5478 (2010).

6. T. Ishihara, Solid Oxide Fuel Cells, 1, 2009.

7. W. Araki, Y. Arai, J. Malzbender, Mater. Lett. 295, 132 (2014).

8. E. Bucher, A. Egger, P.Ried, W. Sitte, P. Holtappels, Solid State Ionics., 179, 1032 (2008).

9. Z. Shao, S.M. Haile, Nature.431, 170 (2004).

10. A.Mineshige, J. Izutsu, M. Nakamura, K. Nigaki, J. Abe, M. Kobune, S. Fujii, T. Yazawa, Solid State Ionics., 176, 1145 (2005) .

11. K. Lu, F. Shen, Int. J. Hydrogen Energy., 39, 7963 (2014).

12. R. Kiebach, W. Zhang, W. Zhang, M. Chen, K. Norrman, H. Wang, J.R. Bowen, R. Barfod, P. Vang, J. Power Sources, 283, 151 (2015).

13. F. Wang, M. Nishi, M.E. Brito, H. Kishimoto, K. Yamaji, H. Yokokawa, T. Horita, J. Power Sources, 258, 281 (2014).

14. M.Z. Khan, M.T. Mehran, R.H. Song, J.W. Lee, S.B. Lee, T.H. Lim, S.J. Park, Ceram. Int., 42, 6978 (2016).

15. M. Liu, M. Liu, D. Ding, K. Blinn, X. Li, L. Nie, Int. J. Hydrogen Energy, 37, 8613 (2012).

16. Y. Leng, S.H. Chan, Q. Liu, Int. J. Hydrogen Energy. 33, 3808 (2008).

17. H.J. Hwang, J.W. Moon, S. Lee, E.A. Lee, J. Power Sources, 145, 243 (2005).

18. L. Agun, H. Abd. Rahman, S. Ahmad, A. Muchtar, Adv. Mater. Res., 893, 732 (2014).

19. S. Gangopadhayay, T. Inerbaev, A.E. Masunov, D. Altilio, N. Orlovskaya, ACS Appl. Mater. Interfaces, 1, 1512 (2009).

20. D.N. Mueller, R. a De Souza, T.E. Weirich, D. Roehrens, J. Mayer, M. Martin, Phys. Chem. Chem. Phys., 12, 10320 (2010).

21. D.N. Mueller, R.A. De Souza, H.I. Yoo, M. Martin, Chem. Mater.,24, 269 (2012).

22. S. Mcintosh, J.F. Vente, W.G. Haije, D.H.A. Blank, H.J. M. Bouwmeester, Chem. Mater.,18, 2187 (2006) .

23. J.S. Kim, D.H. Yeon, D.W. Jung, C. Kwak, J. Power Sources, 249, 66 (2014).

24. M. Arnold, Q. Xu, F.D. Tichelaar, A. Feldhoff, Chem. Mater, 21, 635 (2009).

25. S. Tanasescu, Z. Yáng, J. Martynczuk, V. Varazashvili, F. Maxim, F. Teodorescu, A. Botea, N. 


\section{P. Carpanese et al.: Characterisation of $\mathrm{La}_{0.6} \mathrm{Sr}_{0.4} \mathrm{Co}_{0.2} \mathrm{Fe}_{0.8} \mathrm{O}_{3-\delta}-\mathrm{Ba}_{0.5} \mathrm{Sr}_{0.5} \mathrm{Co}_{0.8} \mathrm{Fe}_{0.2} \mathrm{O}_{3-\delta \ldots} \ldots$}

Totir, L.J. Gauckler, J. Solid State Chem, 200, 354 (2013).

26. F. Deganello, L.F. Liotta, G. Marcì, E. Fabbri, E. Traversa, Mater. Renew. Sustain. Energy, 2, 8 (2013) .

27. K. Efimov, Q. Xu, A. Feldhoff, Chem. Mater, 22, 5866 (2010).

A. Yan, V. Maragou, A. Arico, M. Cheng, P. Tsiakaras, Appl. Catal. B Environ,76, 320 (2007).

28. M. Arnold, H. Wang, A. Feldhoff, J. Memb. Sci, 293, 44 (2007).

29. M. Cimenti, V.I. Birss, J.M. Hill, Fuel Cells, 7, 377 (2007).

30. J. Winkler, P.V. Hendriksen, N. Bonanos, M. Mogensen, J. Electrochem. Soc., 145, 1184 (1998).

31. M. P. Carpanese, A. Giuliano, M. Panizza, E Mercadelli, A. Sanson, A. Gondolini, A. Bertei, A. Barbucci, Bulg. Chem. Commun., 4, 23 (2015) .

32. M.P. Carpanese, M. Panizza, M. Viviani, E. Mercadelli, A. Sanson, A. Barbucci, J. Appl. Electrochem. , 45, 657(2015).

33. M. Koyama, C. Wen, K. Yamada, J. Electrochem. Soc., 147, 87 (2000).

34. M.C. Kim, S.J.A. Park, J. Mater. Sci. Lett., 9, 102 (1990).

35. M. V. Patrakeev, J.A. Bahteeva, E.B. Mitberg, I.A. Leonidov, V.L. Kozhevnikov, K.R. Poeppelmeier, J. Solid State Chem., 172 , 219 (2003).

36. S. Pang, X. Jiang, X. Li, Q. Wang, Z. Su, Int. J. Hydrogen Energy .37, 2157 (2012).

37. G.M. Rupp, A. Schmid, A. Nenning, J. Fleig, J. Electrochem. Soc., 163, F564 (2016).

38. R. Amin, K. Karan, J. Electrochem. Soc., 157, B285 (2010).

39. C. Duan, D. Hook, Y. Chen, J. Tong, R. O'Hayre, Energy Environ. Sci. 404, 265 (2016).

40. J.M. Serra, J. Garcia-Fayos, S. Baumann, F. Schulze-Küppers, W.A. Meulenberg, J. Memb. Sci. 447, 297 (2013).
41. J. Jamnik, J. Maier, Phys. Chem. Chem.Phys., 3, 1668 (2001)

42. J. Fleig, A. Schmid, G.M. Rupp, C. Slouka, E. Navickas, L. Andrejs, H. Hutter, L. Volgger, A. Nenning, ActaChim. Slov.63, 1 (2016).

A. Esquirol, N.P. Brandon, J.A. Kilner, M. Mogensen, J. Electrochem. Soc., 151, A1847 (2004).

43. S.B. Adler, J.A. Lane, B.C.H. Steele, J. Electrochem. Soc. 143, 3554 (1996).

44. T. Kawada, J. Suzuki, M. Sase, A. Kaimai, K. Yashiro, Y. Nigara, J. Mizusaki, K. Kawamura, H. Yugami, J. Electrochem. Soc.,149, E252 (2002).

45. B. Hirschorn, M.E. Orazem, B. Tribollet, V. Vivier, I. Frateur, M. Musiani, Electrochim. Acta.55, 6218 (2010).

46. C.R. Kreller, T.J. McDonald, S.B. Adler, E.J. Crumlin, E. Mutoro, S.J. Ahn, G.J. la O', Y. ShaoHorn, M.D. Biegalski, H.M. Christen, R.R. Chater, J. A. Kilner, J. Electrochem. Soc., 160, F931 (2013).

47. J. Jamnik, J. Maier, S. Pejovnik, Electrochim. Acta., 44, 4139 (1999)

48. M. Søgaard, P. VangHendriksen, M. Mogensen, J. Solid State Chem., 180, 1489 (2007).

49. M. Kuhn, Y. Fukuda, S. Hashimoto, K. Sato, K. Yashiro, J. Mizusaki, J. Electrochem. Soc.160, 34 (2013).

50. D.N. Mueller, M.L. Machala, H. Bluhm, W.C. Chueh, Nat. Commun. 6, 6097 (2015).

51. W.G. Wang, M. Mogensen, Solid State Ionics. 176 457 (2005).

52. K. Park, S. Yu, J. Bae, H. Kim, Y. Ko, Int. J. Hydrogen Energy,35, 8670 (2010).

53. C. Endler, A. Leonide, A. Weber, F. Tietz, E. IversTiffée, ECS Trans. 25, 2381 (2009).

54. J. Kim, S. Choi, A. Jun, H.Y. Jeong, J. Shin, G. Kim, ChemSusChem, 7, 1669 (2014).

55. S. Baumann, F. Schulze-Küppers, S. Roitsch, M. Betz, M. Zwick, E.M. Pfaff, W.A. Meulenberg, J. Mayer, D. Stöver, J. Memb. Sci., 359, 102 (2010). 


\title{
ОХАРАКТЕРИЗИРАНЕ НА $\mathrm{La}_{0.6} \mathrm{Sr}_{0.4} \mathrm{Co}_{0.2} \mathrm{Fe}_{0.8} \mathrm{O}_{3-\delta^{-}} \mathrm{Ba}_{0.5} \mathrm{Sr}_{0.5} \mathrm{Co}_{0.8} \mathrm{Fe}_{0.2} \mathrm{O}_{3-\delta}$ КОМПОЗИТ КАТО КАТОДЕН МАТЕРИАЛ ЗА SОFС
}

\author{
М.-П. Карпанезе $\mathrm{e}^{1,2}$, Д. Клематис ${ }^{*}$, М. Вивиани ${ }^{2}$, С. Престо ${ }^{2}$, М. Паница ${ }^{1}$, Дж. Керисола ${ }^{1}$, А. Барбучи ${ }^{1,2}$ \\ ${ }^{1}$ Катедра по гражданско, химическо и екологично инженерство (DICCA), Университет Генуа, \\ P.le.F.Kennedy 1, I-16129 Генуа, Италия \\ ${ }^{2}$ Институт по химия и технологии за енергия, Национален съвет за научни изследвания (CNR-ICMATE), \\ Via De Marini 6, 16149 Генуа, Италия
}

Постьпила на 14 август, 2017г.; Приета за печат на 24 септември 2017 г.

(Резюме)

Смес от $\mathrm{La}_{0.6} \mathrm{Sr}_{0.4} \mathrm{Co}_{0.2} \mathrm{Fe}_{0.8} \mathrm{O}_{3-\delta}$ and $\mathrm{Ba}_{0.5} \mathrm{Sr}_{0.5} \mathrm{Co}_{0.8} \mathrm{Fe}_{0.2} \mathrm{O}_{3-\delta}$, е изследвана като перспективен катоден материал за горивни клетки с твърдооксидни форивни клетки, работещи при междинна температура(IT-SOFCs). Двата перовскита притежават висока каталитична активност за редукция на кислорода (ORR), въпреки че някои проблеми, свързани с тяхната химическа и структурна стабилност, все още трябва да бъдат преодолени с оглед подобряване на стабилността на характеристиките на клетката. Постигането на стабилен и високоефективен композитен материал е целта на това изследване. По принцип химическото равновесие при интерфейса LSCFBSCF може да бъде постигнато чрез интердифузия на йони по време на процеса на синтероване, което води до химическа стабилизация на материала. Композитният катод, отложен върху $\mathrm{Ce}_{0.8} \mathrm{Sm}_{0.2} \mathrm{O}_{2-\delta}$ електролит, след това беше изследван чрез електрохимична импедансна спектроскопия (EIS) като функция на температурата, свръхпотенциала и времето. Резултатите показаха интересно електрохимично поведение на електрода по отношение на кислородната редукция. XRD анализът е извършен за откриване на структурна модификация по време работа и е установено, че след синтероване двата изходни перовскити вече не присъстват; формира се нова фаза с ромбоедрична структура $\mathrm{La}_{0,4} \mathrm{Sr}_{0,6} \mathrm{FeO}_{3}(\mathrm{LSF})$. Подобрената устойчивост на композитния катод е открита при разглежданите работни условия $\left(200 \mathrm{mAcm}^{-2}, 700^{\circ} \mathrm{C}\right)$ в сравнение с чистия BSCF електрод. Резултатите потвърдиха този нов електрод като перспективна система за по-нататъшно изследване като IT-SOFC катод.

Ключови думи: SOFC катод, дългосрочна стабилност, LSCF-BSCF 